\title{
Juridical Analysis of Bankruptcy Statement Based on Commercial Court's Verdict to Commanditaire Vennootschap
}

\author{
Henny Damaryanti ${ }^{1}$, Aleksander Sebayang ${ }^{2}$, Annurdi $^{3}$ \\ Faculty of Law, Panca Bhakti University $1,2,3$ \\ nurdi.recht@gmail.com
}

\section{Keywords :}

Bankcruptcy, Vennootschap.

\begin{abstract} commanditaire vennootshcap $(\mathrm{CV})$ has some debts to other parties, which is the debt is one of the requirements in the petition for bankruptcy statement. Based on this matter, it is interesting to examine the verdict of commercial court related to the declaration of bankruptcy decision experienced by $C V$ as a non-legal entity. This research type is normative juridical research, and the data used for this research are some legislations, documents and books relating bankcruptcy law. The result of this research revealed that $C V$ is a non-legal entity. Thus, it should not be a CV. Maju Jaya Bogor that is declared bankrupt in this case, but complementary ally (active) from CV Maju Jaya Bogor.
\end{abstract}

Commanditaire In conducting businessactivity, it is possible that a

\section{INTRODUCTION}

The term of business entity, also known as a company. Where business entity and companies are an entity that conducts certain business activities that have a goal to gain profit. The defitnition of company based on Act. Number 3 on 1982 concerning Obligation of Company Register, that is :

"The Company is any form of business that carries on any kind of business which is permanent and continuous and which is established, operated and domiciled within the territory of the Indonesian Republic for the purpose of obtaining profit."

In addition to the definition based on the regulations as described above, there is also the definition of the company according to experts. Such as the definition of the company according to Molengraaff, which states that the company is a whole action perpetrated continuously, acting out to earn income, by trade, deliver goods or enter into a trade agreement.

Based on the description of the definition of the business entity (company) above, it can be recognized that a company obtains profits based on its business activities, so it can be mapped that the company is carrying out economic activities.

Furthermore Sri Redjeki Hartono, stated that the economic activity is essentially the activity of running the company, which is an activity that implies that the activity in question must be done are

1. Continuously in the sense of not intermittent; 
2. Be openly in the legal sense (not illegal); and

3. The activity is conducted in order to gain profit, either for yourself or others.

Furthermore based on the status of legal entities, business entities in theoretically can be classified in 2 (two) forms, namely:

1. Business entity that is not a legal entity; and

2. Business entity in the form of legal entity.

Business entities that are not legal entity are essentially forms of companies established and owned by private parties. Some form of business entity that are not legal entity include civil partnerships, firms and civil partnerships. Meanwhile, the business entity in the form of legal entity to make the company other than as actors in economic activities as well as legal subjects.

According to the legal doctrine, an entity shall be a legal entity if it meets the following criteria or conditions:

1. there is a separate wealth,

2. have a specific purpose,

3. have it's own interests, and

4. there is an organized organization.

As has been described above, it can be seen that the partnership partnership is one form of business entity that is not legal entity. The definition of Commanditaire Vennootschap (CV), based on Article 19 of the Book of Commercial Law (KUHD) is :

"Paragraph 1: A money-giving alliance, also called a partnership alliance, is established between one person or some of the responsible allies responsible for the whole of one and one or more persons as a money-lender on the other."

"Paragraph 2: Thus a failure can occur, a fellowship at one and the same time is a firm fellowship of the allies of the firm within it and is a partnership alliance of the moneylender."

Based on the definition of Commanditaire Vennootschap (CV) as described above, it can be seen that in a civil partnership there are two types of allies that are allies who deposit capital (allied commanditaire) and allied / active (complementary allies) partners. As a business entity, a partnership partnership may have a debt to another party and it is possible that the debts held by the civil union have matured. The existence of such debt is one of the elements that may result in the application of bankruptcy to the partnership partnership as regulated in Law Number 37 on 2004 concerning Bankruptcy and Suspension of Payment Obligation (UUKPKPU).

\section{METHOD}

This study aims to examine the implementation of bankruptcy law against the verdict of bankruptcy on the commanditairevennootschap byanalyzing the Decision Number : 54 / Bankruptcy / 2012 / PN.NiagaJkt.Pst. This study is a normative juridical research, because it uses secondary data or often also referred to as literature research. Normative legal research is a legal research that lays law as a norm system building. The system of norms is about the principles, norms, rules of legislation, court decisions, agreements and doctrines. Secondary data used in this study include legislation relating to the law of agreement and consumer protection, documents and writings relating to the problems studied.

Methods of data analysis used in this research is descriptive qualitative, meaning authors will present and explain the data obtained from the study of literature, which is manifested in a logical and systematic description. Once the ingredients necessary legal collected, the next step was made and analysis to clarify the settlement of the problem, then the conclusions drawn deductively, from things that are common to the things that are special. At this stage the legal material worked on and utilizedin 
such a way to successfully conclude the truth of which can be used to address the issues raised in the study.

\section{RESULTS AND DISCUSSIONS}

Bankruptcy is a seizure that is executed by the court and executes all the debitor's assets for the benefit of all creditors. Then the definition of bankruptcy, also contained in Law No. 37 on 2004 concering Bankruptcy and PKPU, states that :

"Bankruptcy is a common place for all the wealth of Debtor whose management and clearance are conducted by the Curator under the supervision of the Supervising Judge as stipulated in this Law."

Based on the definition of bankruptcy, it can be seen that in general bankruptcy can be interpreted as an attempt to confiscation of debtors bankrupt property in order to guarantee the settlement of creditors' receivables. The real bankruptcy is for:

1. Prevent confiscation and execution demanded by creditors on an individual basis;

2. Intended only on the debtor's property, not personally. Thus, the debtor remains competent to perform legal acts outside the law of wealth.

Regarding the requirement of filing a petition for bankruptcy declaration is regulated in Article 2 paragraph (1) of Law Number 37 on 2004 concerning Bankruptcy and Postponement of Debt Payment Obligation stating that :

"Debtor with two or more Creditors and does not pay at least one debt that has fallen out and is billed, is declared bankrupt by the Court's decision, either on his own petition or on the request of one or more of his creditors".

Further according to Kartono, bankruptcy contains juridical requirements, as follows:

1. The existence of the debtor

2. The existence of creditors

3. The existence of debt

4. Minimum one debt has matured

5. At least one debt can be billed

6. Creditor more than one

7. A bankruptcy statement is made by a court decision.

As described above, the debtor is a party that can be declared in a bankrupt state. In connection with this, the question arises about the imposition of bankruptcy declaration addressed to the commanditaire vennootschap, which in this study is subject to decision Number: 54/ Bankruptcy/2012/PN.NiagaJkt.Pst., Where in this decision the commercial court dropped the bankrupt decision against the CV. MajuJaya Bogor. As previously discussed, the partnership is a non-legal entity. Based on Article 19 KUHD mentioned that the commanditaire vennootschap (CV) is:

"A partnership to run a company formed between one person or several associates who directly bear responsibility and responsibility for all (solidarity responsibility) on the one hand, and one or more persons as money-lenders on the other."

In relation to that regulation, to know about the imposition of the bankruptcy decision to commanditairevennootschap, it is necessary to know the party that can be declared bankrupt based on the verdict of the commercial court. The parties that can be declared bankrupt, among others:

1. Individuals, men and women, both married and unmarried. If the request for bankruptcy declaration is filed by a married individual debtors, then such application may only be filed with the consent of the husband or wife, except between the spouses there is no mixing of property;

2. Unions and associations are not other legal entities. An application for a bankruptcy declaration to a firm must contain the names and residence of the respective Persero financially bound for the entire debt of the firm; 
3. Companies, corporations, associations, cooperatives and foundations with legal status. In this case the provisions on the authority of each legal entity as stipulated in its articles of association are stipulated;

4. The treasures of the heritage that have not been distributed to the heirs as a unity of the collection of individual assets.

Furthermore, in case of bankruptcy on CV. Maju Jaya Bogor based on Verdict Number: 54 / Bankruptcy / 2012 / PN.NiagaJkt.Pst., In this case PT.BankInternasional Indonesia, Tbk., Acting as the applicant and CV. Maju Jaya Bogor as the party pleaded. As for the case it is known that :

1. CV. Maju Jaya Bogor has debt to:

a. PT.BankInternasional Indonesia, Tbk.

b. PT.Bank Rakyat Indonesia (Persero) Tbk, Bogor Pajajaran Branch Office, Jl. Raya Pajajaran No. 96 A-B Bogor 16153.

c. PT.Bank Negara Indonesia (Persero) Tbk, Branch Office of Bogor, Jl. Ir. H Juanda No.52, Lt. 3, Bogor 16001.

2. Since June, 2009 up to the date the Respondent Bankrupt no longer pays the debt obligations to the Bankrupt Applicant and has neglected to return all of its obligations, even though the above Credit Agreement has expired (due) on August 6, 2009 and the Applicant Bankrupt has given several times of reprimand to the Respondent for Bankruptcy, lastly through letter no. S-31 / SOM / TGE / 0712 dated July 4, 2012, concerning the Somation and Default Statement and Letter No. S-32 / SOM / TGE / 0712 dated July 4, 2012 regarding the somation and the statement of breach of contract.

3. Based on Letter of PT.Bank Rakyat Indonesia (Persero) Tbk, Branch Office of Bogor Pajajaran, with NoB.1202a-KC / XIV / KRD / 07/2012, dated July 25, 2012 regarding Debtor Information CV.Maju Jaya Bogor, addressed to the Office The Law of Teddy, Gunawan\&Emron as Legal Counsel of the Petitioners of Bankruptcy, confirms the truth that the Respondent Bankrupt is a Debtor of PT Rakyat Indonesia (Persero) Tbk, Bogor Pajajaran Branch Office and collectibility / Credit Performance Loss; and

4. Based on the Original Document of Bank Indonesia Report No. Report 14/58840111 / DPIP / PIK Date of Report 08/08/2012 for the Last Data Position 31/07/2012, the Respondent Bankrupt also has a debt to PT.Bank Negara Indonesia (Persero) Tbk, Bogor Branch with Collectibility 5 (Loss).

Based on these facts, it has fulfilled the element or requirement of bankruptcy as regulated in Article 2 paragraph (1) of Law Number 37 on 2004 concerning Bankruptcy and PKPU. In connection with this, the Commercial Court at the Central Jakarta District Court handed down the bankruptcy verdict against the CV. Maju Raya Bogor pursuant to Verdict Number: 54 / Bankruptcy / 2012 / PN.NiagaJkt.Pst., However according to the provisions in such as has been described above, the commanditairevennootshcap is a business entity (not a legal entity), so it can not be declared bankrupt,but more precisely in this declared bankruptcy is an allied member of the it's alliance. This is in accordance with the opinion of Adrian Sutedi, which states that:

"Because a CV is not a legal entity, so it is not possible to bankruptcy. CV bankruptcy means bankruptcy from its ally, not of its alliance. Each of the allies is solely responsible for the alliance of its commanditaire vennootshcap. The debts that did not paid by CV are the debts of the CV's member.

Furthermore, based on Article 19 and Article 20 of the Commercial Code expressly states, that in a partnership alliances there are 2 (two) allies, namely:

1. A complementary ally who is an ally who carries out a partnership and is jointly responsible for the whole.

2. Allied commanders who are allies who enter the capital, and responsible for on capital entered by him.

In connection with the bankruptcy experienced by a commanditairevennootshcap, Mulhadi argues that: 
"In the case of a bankruptcy on $\mathrm{CV}$, the legally responsible is a complementary ally, since a complementary ally is an ally of the board responsible for the course of the fellowship."

So in this case that is responsible for the entire debt CV. Maju Raya Bogor is a complementary ally because complementary allies are responsible for the entire debt of CV. Maju Raya Bogor, so in this case the authors argue that complementary allies on the CV. Maju Raya Bogor which is responsible for bankruptcy experienced by CV. Maju Raya Bogor.

\section{CONCLUSION AND SUGGESTION}

In the bankruptcy that experienced by the CV. Maju Raya Bogor, then basically declared bankrupt in the case is complementary ally (active) of CV. Maju Raya Bogor. This is caused by the fact that the $\mathrm{CV}$ is a non-legal entity and furthermore the ally of complementary partners (active) of CV. Maju Raya Bogor is the party who has responsibility for the obligation or debt for the whole. Thus, it should not be a CV. Maju Jaya Bogor that is declared bankrupt in this case, but complementary ally (active) from CV Maju Jaya Bogor.

\section{REFERENCES}

Kitab Undang-Undang Hukum Dagang

Undang-Undang Nomor 37 tahun 2004 tentang Kepailitandan PKPU.

Dewata, Mukti, F.N \& Yulianto, A. (2010). Dualisme Penelitian Hukum Normatif \& Empiris. Yogyakarta: Pustaka Pelajar,.

Hartono, S, R. (2000). Kapita Selekta Hukum Ekonomi. Bandung: PT Mandar Maju,.

Irawan, Bagus. (2007). Aspek-aspek Hukum Kepailitan; Perusahaan; dan Asuransi: (AnalisisYuridis tentang Kepailitan ; Perusahaan; dan Asuransi Manulife dan Prudential). Bandung: PT. Alumni.

Muhammad, A. (1991). Hukum Perusahaan. Bandung: PT. Citra Aditya Bakti,.

Mulhadi.( 2010). Hukum Perusahaan :Bentuk-bentuk Badan Usaha di Indonesia. Bogor: Ghalia Indonesia,.

Rahardjo, S. (1996). Ilmu Hukum. Bandung: PT Citra Aditya Bakti.

Situmorang, V, M. \& Hendri, S. (1994). Pengantar Hukum Kepailitan di Indonesia. Jakarta: Rineka Cipta.

Soekardono, R. (1983). Hukum Dagang Indonesia, Jilid I (bagianpertama). Jakarta: Dian Rakyat,.

Sutedi, A. (2009). Hukum Kepailitan. Bogor: Ghalia Indonesia.

Waluyo, B. (1999). Hukum Kepailitan dan Penundaan Kewajiban Pembayaran Utang. Bandung: Mandar Maju.

Widjaja, G. (2009). Resiko Hukum dan Bisnis Bila Perusahaan Pailit. Jakarta: Forum Sahabat,. 